\title{
FLUKTUASI ASIMETRI IKAN NILA 69 (Oreochromis niloticus) DARI DANAU TEMPE (SULAWESI SELATAN) DAN IKAN NILA GIFT DARI SUKAMANDI, JATILUHUR, DAN SUKABUMI
}

\author{
Ani Widiyati*) dan Komar Sumantadinata**)
}

\begin{abstract}
ABSTRAK
Fluktuasi asimetri organ berpasangan merupakan salah satu metode sederhana yang dapat digunakan untuk menghitung keragaman fenotip pada ikan nila. Penelitian ini bertujuan untuk mengukur fluktuasi asimetri ikan nila 69 dari Danau Tempe (Sulawesi Selatan) dan ikan nila GIFT dari Sukamandi, Jatiluhur, dan Sukabumi. Ikan nila yang digunakan berukuran konsumsi (150-250 g/ekor) dan berasal dari masing-masing lokasi diukur 50 ekor sebagai ikan uji. Hasil penelitian menunjukkan bahwa ikan nila 69 dari Danau Tempe mempunyai nilai fluktuasi asimetri bilangan (Fan) dan besaran (Fam) gabungan terkecil yaitu 0,8 dan 2,84. Ikan nila dari Jatiluhur mempunyai nilai fluktuasi asimetri bilangan (Fan) dan besaran (Fam) gabungan tertinggi yaitu 4,43 dan 16,66 .
\end{abstract}

ABSTRACT: Fluctuating asymmetry of nile tilapia 69 (Oreochromis niloticus) from Lake Tempe (South Sulawesi) and GIFT nile tilapia from Sukamandi, Jatiluhur, and Sukabumi. By: Ani Widiyati and Komar Sumantadinata

The asymmetric fluctuating of couple organs were used as simple method to calculate fenotype variation of nile tilapia. The objective of this study was to measure the asymmetric fluctuation nile tilapia 69 from Lake Tempe (South Sulawesi) and nile tilapia GIFT product from West Java (Jatiluhur, Cirata, Sukamandi, and Sukabumi). The results showed that nile tilapia from Lake Tempe had the smallest value of fluctuating asymmetry number (Fan) and magnitute (Fam), which are 0.8 and 2.84 prespectively. The biggest value of fluctuating asymmetry number (Fan) and magnitute (Fam), which are 4.43 and 16.66 respectively.

\section{KEYWORDS: fluctuating asymmetry, nile tilapia, Lake Tempe, West Java}

\section{PENDAHULUAN}

Ikan nila merupakan salah satu ikan introduksi dari Sungai Nil di Afrika, dibawa masuk ke Indonesia dari Taiwan pada tahun 1969. Ikan nila disukai oleh pembudi daya karena mempunyai pertumbuhan yang lebih cepat dibandingkan dengan ikan mujair (Widiyati \& Sudarto, 1995). Permintaan ikan nila konsumsi untuk pasar lokal (ukuran individu 100-300 g/ekor) semakin meningkat, pangsa pasar semakin luas dengan adanya permintaan ikan tersebut untuk ekspor (ukuran individu di atas $500 \mathrm{~g} /$ ekor). Untuk memenuhi kebutuhan pasar ekspor maka diperlukan ikan nila dengan pertumbuhan cepat dan ukuran individu yang besar.

Permasalahan yang sudah lama dihadapi oleh pembudi daya ikan nila adalah kecenderungan penurunan pertumbuhan, ukuran individu mengecil, matang gonad pada usia dini (Widiyati \& Sudarto, 1995). Menurut Leary et al. (1985), rendahnya kualitas genetik akan berakibat negatif terhadap sifat-sifat penting dalam budi daya ikan, antara lain

\footnotetext{
") Peneliti pada Balai Riset Perikanan Budidaya Air Tawar, Bogor

**) Fakultas Perikanan dan Ilmu Kelautan, Institut Pertanian Bogor
} 
menurunnya tingkat sintasan dan pertumbuhan ikan. Fenomena ini juga dicirikan dengan meningkatnya individu yang asimetri dan abnormal. Hal ini terlihat dari perbedaan bentuk ukuran, jumlah, dan ciri morfologi yang lain pada organ berpasangan antara organ bagian kiri dan kanan (Wilkins et al., 1995).

Informasi tentang keragaman genetik yang dimiliki oleh setiap populasi akan menjadi dasar dalam melakukan program pemuliaan ikan, sehingga keberhasilan program tersebut sangat bergantung pada sumber keanekaragaman genetiknya. Pengukuran keragaman genetik ikan dapat dilakukan berdasarkan karakter morfologi (meristik, morfometrik, dan fluktuasi asimetri), serta karakter genotipnya (isozyme, DNA mitokondria, DNA mikrosatelit). Pengukuran keragaman genetik dengan menghitung jumlah organ-organ berpasangan yang asimetri lebih mudah dilakukan serta dengan biaya yang jauh lebih murah dibandingkan dengan pengukuran berdasarkan karakter genotipnya.

Menurut Clarke (1992), kestabilan perkembangan organ-organ berpasangan pada hewan berhubungan erat dengan tingkat keragaman genetiknya. Kestabilan organorgan berpasangan disebut dengan fluktuasi asimetri. Nilai stabilitas perkembangan organ berpasangan diukur dengan dua angka, yaitu dengan bilangan (number) rataan sifat asimetri per individu dengan angka rataan besaran (magnitute) asimetri. Pengukuran stabilitas perkembangan dengan kedua angka tersebut pada setiap individu yang kemudian diperoleh nilai tengah dari keseluruhan asimetri dapat digunakan untuk menduga berkurangnya keragaman genetik akibat silang dalam suatu populasi ikan (Leary et al., 1985).

Young et al. (1995) menyatakan bahwa adanya asimetri bilateral pada ikan rainbow trout signifikan dengan peningkatan homosigositas pada ikan tersebut. Menurut Nurhidayat (2000), pada ikan lele dumbo asal Sleman, Tulungagung, dan Bogor ditemukan stabilitas perkembangan organ tubuh yang rendah pada sirip dada dan sirip perut, hal ini diduga akibat mengalami tekanan silang dalam.

Penelitian ini bertujuan untuk mengetahui fluktuasi asimetri ikan nila 69 (Oreochromis niloticus) dari Danau Tempe (Sulawesi Selatan), dan ikan nila GIFT dari Sukamandi, Jatiluhur, dan Sukabumi.

\section{BAHAN DAN METODE}

Ikan uji yang digunakan untuk penelitian ini adalah 5 strain ikan nila yang didatangkan pada tahun 1969. Ikan nila 69 tersebut berasal dari Danau Tempe, ikan nila dari Balitkanwar Sukamandi (nila GIFT generasi 6 introduksi tahun 1997), pembudi daya ikan Sukabumi (turunan nila GIFT dari generasi 3 introduksi tahun 1995), pembudi daya ikan KJA di Jatiluhur (nila GIFT turunan generasi 3), dan pembudi daya ikan Cirata (nila GIFT turunan generasi 3 dari Balai Budidaya Air Tawar Sukabumi). Ikan uji dari masing-masing lokasi sebanyak 50 ekor dengan ukuran $150-250 \mathrm{~g} / \mathrm{kg}$.

Penelitian dilakukan dengan metode deskriptif, yaitu mendeskripsikan berbagai peubah secara umum yang dikelompokkan sebagai karakter morfologi sedangkan untuk menghitung fluktuasi asimetri dilakukan pengukuran mengikuti metode dari Leary et al. (1985) yaitu dengan cara menghitung ciri meristik bilateral yang terdiri atas jumlah jarijari lemah sirip dada, jari-jari lemah sirip perut, sisik pada garis rusuk (LL), dan tapis insang pertama bagian dalam. Agar lebih mudah dalam penghitungan organ-organ tersebut, ikan nila dimatikan kemudian organ dipisahkan dari tubuh dengan cara memotong bagian pangkal tanpa merusak organ. Selanjutnya pengamatan dilakukan di bawah mikroskop binokuler.

Hasil pengukuran fluktuasi asimetri bilangan (Fan), yaitu jumlah karakter individu asimetri dari sejumlah individu yang diamati dapat diketahui dengan rumus (Leary et al., 1985).

$$
\mathrm{Fan}=\frac{\Sigma\left[\mathrm{Z}_{\mathrm{i}}\right]}{\mathrm{N}}
$$

di mana :

Fan = fluktuasi asimetri bilangan

$\mathrm{Zi} \quad=$ jumlah individu asimetri untuk ciri meristik tertentu

$\mathrm{N}=$ jumlah contoh

Sedangkan untuk fluktuasi asimetri besaran (Fam) yaitu jumlah absolut perbedaan karakter organ kiri dengan kanan dari sejumlah individu yang diamati dapat dihitung dengan rumus:

$$
\operatorname{Fam}=\frac{\sum\left[\mathrm{x}_{\mathrm{i}}-\mathrm{y}_{\mathrm{i}}\right]}{\mathrm{N}}
$$


di mana:

$$
\begin{aligned}
& \mathrm{Fam}=\text { fluktuasi asimetri besaran } \\
& \mathrm{Xi}=\text { jumlah organ kiri } \\
& \mathrm{Yi}=\text { jumlah organ kanan } \\
& \mathrm{N} \quad=\text { jumlah contoh }
\end{aligned}
$$

Selanjutnya dari hasil perhitungan nilai fluktuasi asimetri bilangan (Fan) dan fluktuasi asimetri besaran (Fam) dapat digunakan untuk pendugaan terhadap heterozigositas / homozigositas gen pada ikan. Jika nilainya semakin besar maka diduga heterosigositas gen semakin kecil atau homozigositasnya semakin besar.

\section{HASIL DAN BAHASAN}

Nilai fluktuasi asimetri bilangan (Fan) dan besaran (Fam) gabungan organ berpasangan seperti jari-jari lemah sirip dada, jari-jari lemah sirip perut, tapis insang, sisik linealateralis atas dan bawah ikan nila, terbesar diperoleh dari ikan nila GIFT Jatiluhur yaitu 4,43 dan 16,66; dan terkecil diperoleh dari ikan nila dari Danau Tempe yaitu 0,8 dan 1,4 (Tabel 1). Untuk hasil pengukuran fluktuasi asimetri gabungan baik besaran (Fam) dan bilangan (Fan) dari Danau Tempe mempunyai nilai paling kecil. Hal ini diduga karena heterozigositas gen ikan nila dari Danau Tempe paling tinggi dibandingkan dari Cirata, Jatiluhur, Sukamandi, dan Sukabumi.

Nilai fluktuasi asimetri ikan nila dari Sukamandi paling kecil di antara hasil budi daya (GIFT). Hal ini disebabkan ikan nila dari Sukamandi adalah ikan nila GIFT generasi 6 dari ICLARM Filipina, di mana ikan ini adalah ikan seleksi famili yang belum disebarluaskan dan dipijahkan oleh pembudi daya ikan nila. Fenomena tersebut memperlihatkan bahwa mutu genetik ikan nila GIFT dari Sukamandi lebih baik dibandingkan dengan ikan nila GIFT dari Jatiluhur dan Sukabumi.

Nilai fluktuasi asimetri terbesar adalah ikan nila dari Jatiluhur, tingginya nilai tersebut diduga tingkat homozigositas ikan paling tinggi dibandingkan ikan nila dari Danau Tempe, Sukamandi, Sukabumi, dan Cirata. Dari hasil wawancara dengan pembudi daya ikan nila dari Cirata dan Jatiluhur, mereka memperoleh benih dari unit perbenihan rakyat (UPR) dari Sukabumi. Pada umumnya kegiatan perbenihan di UPR di Sukabumi tidak memperhatikan teknik pemuliaan. Selain itu pembudi daya juga tidak mempunyai data tentang silsilah tetua, jumlah pasangan induk ikan yang dipijahkan, dan frekuensi pemijahan. Pembenih ikan nila biasanya hanya memiliki induk sedikit (10-25 pasang) karena mereka berpendapat lebih ekonomis dalam pemeliharaannya.

Menurut Tave (1986), jika perkawinan mengabaikan tetua, peluang terjadinya inbreeding sangat besar. Selanjutnya dikatakan pula, untuk menghindari terjadinya inbreeding tersebut sebaiknya pemijahan dilakukan minimal menggunakan 50 pasang induk. Hal ini sesuai dengan hasil penelitian Nurhidayat (2000) yang menyatakan bahwa fluktuasi asimetri pada ikan lele dumbo relatif lebih tinggi dibandingkan ikan nila, berarti keragaman genetik ikan lele dumbo tersebut lebih rendah dibandingkan ikan nila hasil penelitian ini.

Rendahnya nilai keragaan pada pembenih ikan lele dumbo diduga karena penggunaan pasangan induk yang dipijahkan sedikit yaitu 1-2 pasang induk (Nurhidayat, 2000), sedangkan pada ikan nila paling sedikit 10

Tabel 1. Nilai fluktuasi asimetri bilangan (Fan) dan asimetri besaran (Fam) gabungan (jarijari lemah sirip dada, perut, tapis insang, linealateralis atas, dan bawah) dari Danau Tempe (Sulawesi Selatan), Cirata, Jatiluhur, Sukabumi, dan Sukamandi (Jawa Barat)

\begin{tabular}{|c|c|c|}
\hline $\begin{array}{c}\text { Asal ikan } \\
\text { Individual stock }\end{array}$ & $\begin{array}{c}\text { Bilangan ( Fan) } \\
N u m b e r\end{array}$ & $\begin{array}{c}\text { Besaran ( Fam ) } \\
\text { Magnitude }\end{array}$ \\
\hline Cirata & 3,61 & 15,98 \\
\hline Jatiluhur & 4,43 & 16,66 \\
\hline 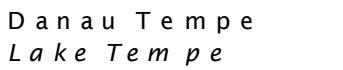 & 0,8 & 1,40 \\
\hline $\mathrm{Sukabumi}$ & 3,91 & 15,19 \\
\hline S u k a mand i & 1,75 & 2,84 \\
\hline
\end{tabular}

Table 1. Fluctuating asimmetry value of number (Fan) and magnitute (Fam) (softray pectoral and ventral fin, branchial arch, and linealateralis) from Lake Tempe (South Sulawesi), Cirata, Jatiluhur, Sukabumi, and Sukamandi (West Java) 
pasang induk. Menurut Leary et al. (1985), rendahnya keragaman genetik berhubungan dengan terjadinya silang dalam yang dapat meningkatkan homozigositas. Jika frekuensi silang dalam meningkat maka akan terjadi perubahan morfologi pada individu tersebut, yang diduga disebabkan oleh meningkatnya homozigositas. Homozigositas tersebut menyebabkan menurunnya kemampuan individu untuk berkembang secara normal. Hal tersebut sesuai dengan pernyataan Tave (1986) bahwa jika suatu organisme memiliki alel resesif yang tersembunyi dalam bentuk homozigot, maka jika alel tersebut muncul akan menyebabkan fenotip yang abnormal.

\section{KESIMPULAN DAN SARAN}

Ikan nila dari Danau Tempe mempunyai nilai fluktuasi asimetri bilangan (Fan) dan besaran (Fam) gabungan terkecil yaitu 0,8 dan 2,84; sedangkan ikan nila dari Jatiluhur mempunyai nilai fluktuasi asimetri bilangan (Fan) dan besaran (Fam) gabungan terbesar yaitu 4,43 dan 16,66.

\section{DAFTAR PUSTAKA}

Clarke, G.M. 1992. Fluctuating asymmetry: A technique for measuring developmental stress of genetic and environmental origin. Acta Zool. Fennica. 191: 31-35.
Leary, R.F., F.W. Allendorf, and K.L. Knudsen. 1985. Development instability and high meristic counts in interspecific hybrid of salmonid fishes. Evolution. 39(6): 1,3181,326 .

Nurhidayat, M.A. 2000. Fluktuasi Asimetri pada Ikan Lele Dumbo (Clarias sp.) yang Berasal dari Tiga Daerah Sentral Budidaya di Pulau Jawa. Tesis. Program Pascasarjana. Institut Pertanian Bogor. 26 pp.

Tave, D. 1986. Genetics for fish hatchery managers. AVI Publishing Company, Inc. Westport, Connecticut. 299 pp.

Widiyati, A. dan Sudarto. 1995. Evaluasi pertumbuhan beberapa strain ikan nila (nila'69, nila GIFT, dan nila Chitralada). Prosiding Seminar Hasil Penelitian Perikanan Air Tawar 1994/1995, Balitkanwar. Sukamandi. p. 44-49.

Wilkins, N.P., E. Gosling, A. Linnane, C. Jordan, and H.P. Courtney. 1995. Fluctuating asymmetry in atlantic salmon, european trout and their hybrids, including triploids. Aquaculture. 137: 77-85.

Young, W.P., P.A. Wheeler, and G.H. Thorgaard. 1995. Asymmetry and variability of meristic characters and spotting in isogenic lines of rainbow trout. Aquaculture. 137: 67-76. 